\title{
Mobile Technology Usage: The Shift of Focus to Cultivate High Level Thinking Skills (HOTS) in the Malay Language Education System
}

\author{
Marzni Mohamed Mokhtar ${ }^{1, *}$, Marni Jamil $^{2}$ \\ ${ }^{1}$ Department of Language and Humanities Education, Faculty of Educational Studies, Universiti Putra Malaysia, Malaysia \\ ${ }^{2}$ Academy of Language Studies, Universiti Teknologi Mara (UiTM) Cawangan Pulau Pinang, Malaysia
}

Received October 27, 2019; Revised December 2, 2019; Accepted December 24, 2019

Copyright $\subseteq 2020$ by authors, all rights reserved. Authors agree that this article remains permanently open access under the terms of the Creative Commons Attribution License 4.0 International License

\begin{abstract}
The rapid growth of information and communication technology has also affected the current education world. Teachers as individuals in charge of teaching and guiding pupils in the classroom need to undertake a paradigm shift related to pedagogy conducted. Teachers should be wise in balancing between the content of knowledge and information to be conveyed and then combine it with other skills, especially the skill of high order thinking (HOTs) by using mobile technology. The use of mobile technology is now increasingly gaining attention in the world community in all matters. Hence, the educational system is able to offer chances and opportunities to embrace high-level thinking by making mobile technology a device that brings about and facilitates teachers to deliver knowledge and skills to pupils of generation $\mathrm{Z}$.
\end{abstract}

Keywords Mobile Technology, High Level Thinking Skills (KBAT), T\&L, Teacher Perception

\section{Introduction}

Both local and global education systems have made mobile technology an avenue to apply higher order thinking skills (HOTs) in teaching and learning (T\&L) instruction, as it is deemed as the latest trend in the pedagogy of Malay Language. The use of mobile learning should be seen as a challenge for teachers in their effort to uphold Malay Language besides ensuring that children learn and master language skills, namely speaking, listening, reading and writing skills. Teachers also play important roles to ensure the success of students at the end of their T\&L instruction, to ensure that the end product could compete, adapt and apply the mastery of knowledge outside the classroom (Mohd Salmi Osman, Maria Chong Abdullah, Abdul Aziz Ismail \& Samsilah Roslan, 2015). In addition, the transformational transition and dependency on mobile technology are parallel with the hope of the Ministry of Education (MOE), which has set the cultivation of HOTs in T\&L as an agenda that needs to be achieved in the National Education Development Plan beginning 2013 until 2025 (KPM, 2013).

Therefore, the practitioners of Malay Language education system should be aware that the responsibility of education not only depends on the students' ability to receive knowledge. In fact, teachers should advocate the philosophy, curriculum, pedagogy and assessment of education as authentic corresponding mechanism to realise the effort to cultivate holistic HOTs (Fuziah Rosman, Norlidah Alias, Mohd Nazri Ab Rahman \& Dorothy Dewitt, 2016). The challenges of transition and dependency on mobile devices entail teachers to contribute ideas, expertise and commitment in facing the waves of change in the education system. The extremely competitive changes of the local and global education systems also challenge the ability of teachers in producing a generation of students who could not only master the language, but also those who could translate the language mastery into their daily demands to suit the evolution of generation.

\section{Statement of Problem}

The discussions about the cultivation of HOTs in T\&L instruction as well as teachers' pedagogical knowledge have garnered the attention of education researchers (Md. Yusof Dawam, 2006; Suhaimi Zakaria @ Othman, Baharuddin Aris, Hasnah Mohammed, Norasykin Mohd Zaid \& Zaleha Abdullah, 2014; Yahya Othman, 2014; Muhamad Sidek Said, 2016). The consensus gathered 
among the researchers found that there was a need to improve HOTs through the use of effective methods, approaches, techniques or learning strategies. As for students' cognitive ability during T\&L, the implementation of various teaching approaches, techniques or strategies acted as boosters to simulate and generate students' HOTs (Shamsuddin Muhammad, Ruzlan Md. Ali \& Siti Noor Ismail, 2016). The methods, approaches, techniques or strategies used to increase the mastery of HOTs in T\&L in the study including the use of questioning techniques (Supramani S., 2006; Tee Tze Kiong, et al., 2011; Wan Mat Sulaiman \& Norkhairiah Hashim, 2011), the use of problem-solving learning (Musliha Salma Mohd Radzi, 2010; Alizah Lambri \& Zamri Mahamod, 2015), the use of self-study thinking skills and Buzan mind mapping (Tee Tze Kiong et al., 2011), the use of SALAK didik element (A Rahman Haron, Jamaludin Badusah \& Zamri Mahamod, 2015 ) and the use of language learning model (Zulkifli Osman, 2015).

However, there were only few researches that involved the application of HOTs in Malay Language subject (A. Rahman Haron, Jamaludin Badusah \& Zamri Mahamod, 2015). Teachers were seen to apply less HOTs in T\&L because they practised conventional teaching method such as 'chalk and talk' instead of two-way teaching method (Nooriza Kassim \& Effandi Zakaria, 2015). Consequently, it was found that student-centred T\&L activities that aimed to expand the use of HOTs through outside of class T\&L activities such as group discussions, games or shows were not being practised by teachers (Shamsuddin Muhammad, Ruzlan Md. Ali \& Siti Noor Ismail, 2016). This scenario is deemed as opposing the needs of $21^{\text {st }}$ century's T\&L instruction that requires teachers to vary their teaching approaches that are concentrated on the elements of HOTs, collaborative skills, communication skills and creativity (Badrul Hisham Alang Osman \& Mohd Nasaruddin Basar, 2016). Hence, the implementation of HOTs in effective $T \& L$ instructions requires teachers' deep understanding upon the needs and demands of the curriculum, the knowledge and pedagogical knowledge, the choice of strategy, the method or teaching approach, as well as the identification of the criteria of different students development (Shamsuddin Muhammad, Ruzlan Md. Ali \& Siti Noor Ismail, 2016; Owi Wei Ping \& Ang Ken Hua, 2017).

Likewise, teachers were also found to disregard the use of consistent application of HOTs in their teaching instruction due to their failure to plan the T\&L process properly (Sharifah Nor Puteh et al., 2012; Sukiman Saad, Noor Shah Saad \& Mohd Uzi Dollah, 2012; Chew Fong Peng \& Shashipriya Nadaraja, 2014; Zulkifli Osman, 2015; Zarina Abdul Rashid, 2016). Failure in planning the application of HOTs in T\&L instruction was also caused by teachers' time constraint in completing the T\&L syllabus, while there are teachers who only applied HOTs in T\&L instruction based on their individual understanding and experience only. This has resulted in teachers being seen as frail and pessimistic in getting information on HOTs, feeling confused to use suitable HOTS teaching strategy, and having insufficient trainings to apply HOTs in T\&L instruction (Zarina Abdul Rashid, 2016; Mohd Nazri Hassana, Ramlee Mustapha, Nik Azimah Nik Yusuffa, Rosnidar Mansor, 2017).

Questioning techniques used by teachers were also found to influence the implementation of HOTs in T\&L. Results showed that teachers were prone to use lower order thinking skills questioning technique in their teaching instruction (Sharifah Nor Puteh et al., 2012; Sukiman Saad, Noor Shah Saad \& Mohd Uzi Dollah, 2012; Chew Fong Peng \& Shashipriya Nadaraja, 2014; Zulkifli Osman, 2015; Zarina Abdul Rashid, 2016). This has in a way caused teachers to teach students to memorise facts and to test students' knowledge through multiple-choice questions tests (Yahya Othman, 2003; Noor Rohana Mansor, 2007a $\& 2007 b$ ). This routine was steered by teachers due to the existence of the belief that students need to acquire prior knowledge about all the facts and concepts of a subject before they are encouraged to think (Mohd Nazri Hassana, Ramlee Mustapha, Nik Azimah Nik Yusuff, Rosnidar Mansor, 2017). This practice is found to be against the effort to implement HOTs in T\&L, which requires teachers to give attention to HOTs that comprise the application, synthesis and analysis, excellent thinking skills and opportunities to organise ideas. As for the implications of future T\&L, teachers were found to face difficulty to teach students the skills of analysing, synthesizing and evaluating some subject contents (Musliha Salma Mohd Radzi, 2010).

Besides that, research also showed that the non-existent modules as guidelines impede the effort to apply HOTs in T\&L (Mohd Nazri Hassana et al., 2017). The application of HOTs in T\&L based on the module sample is crucial for teachers who did not get the opportunity to follow the course or workshop to gain exposure on how to execute the pedagogy that applies HOTs in T\&L. Other than modules, teaching aids also play a role in the application of HOTs in T\&L (James Ang Jit Eng, 2017). The ignorance of these teaching aids and modules could deteriorate the intellectual participation of students in T\&L, as well as the quality of practice and work given to them (Baharuddin Jabar, 2006; Md. Yusof Dawam, 2006; Yahya Othman, 2009).

\section{Literature Review: Mobile Technology}

The dynamic revolutionary world of information technology and communication comprises the structural and technical forms that reflect the changes of ancient era to literacy era, printing era, and electronics era; whereby each era represents a type of specific communication verbal, written, printed, and telecommunication (Siti 
Ezaleila Mustafa \& Azizah Hamzah, 2011). Today, information is produced and equipped with the criteria of convergence, digital network, global network, interaction, and communication by combining the overall communication elements, namely verbal, written, visual, data, and sound elements through the use of computers and telecommunication devices and integrating them via one platform. This can be highlighted in the meaning of mobile technology, which refers to the use of tools or gadgets that consist of mobile phones, personal data assistant (PDA) and tablets that are compact and easily accessible anytime and anywhere (Nurul Syazwani Ismail, Jamalludin Harun \& Shaharuddin Md. Salleh, 2016).

The variety of technologies introduced each day has great influences in our daily lives (Aznan Omar, 2017). This scenario happens because these technological revolutions aim to form a global community that interacts among one another which then brings about the impacts to businesses, education, social sciences, and science and technology. This results in the worldwide acceptance of mobile devices as there is an existence of personal interaction among individuals. There are eight factors that cause the preference of personal interaction (Siti Ezaleila Mustafa \& Azizah Hamzah, 2011). These factors consist of (1) the depletion of the power of dollars; (ii) the talk about marketing; (iii) the creation of new behaviours that stem from globalisation; (iv) the use of CMC by Gen Y or the millennials to replace telephones and face-to-face communication; (v) the increase of research findings on social media; (vi) the contribution of bigger government's findings for technology and human interaction related projects; (vii) the reassessment of issues on humanity and spirituality post-11 September 2001 incidents, and (vii) the importance of social networking as a factor in connecting relationship and successful businesses, as well as the increase of research on social capital. As for their impacts, the education world is not exempted from the rapid development and replacement of mobile technology in the execution of T\&L. As the saying goes, 'everything is at the tip of their fingers and 'a world without borders' are turning into reality in this progressive education system. As a result, the use of technology is apparently not only limited to the use of personal computer.

On the other hand, the focus on the communication world has shifted to the use of mobile technology, which has garnered interest and obsession among the public, especially school children and university students. Previously, the education world went beyond the developmental phase of Web 1.0 technology, known as the World Wide Web (Siti Ezaleila Mustafa \& Azizah Hamzah, 2011; Fuziah Rosman, Norlidah Alias, Mohd Nazri Ab Rahman \& Dorothy Dewitt, 2016), which then led to Web 2.0, that included social webs such as blog, Wikis, podcasts, Friendster, Youtube, Facebook, Twitter, Instagram, Telegram and other applications that created as a business model and e-learning (Siti Ezaleila Mustafa \& Azizah
Hamzah, 2011; Fuziah Rosman, Norlidah Alias, Mohd Nazri Ab Rahman \& Dorothy Dewitt, 2016). Additionally, the revolution of global technology has been replaced with simulations through social computing in the virtual world known as Web 3.0. (Fuziah Rosman, Norlidah Alias, Mohd Nazri Ab Rahman \& DorothyDewitt, 2016). Among the Web 3.0 technologies used are the e-learning applications such as Padlets, EdPuzzle and Screen O Matic. The next shift headed to the Industrial Revolution 4.0, which covers the findings of new technology such as automation, Internet of Things (IoT), analysis and big data, simulation, system integration, robotics and cloud which will enhance the success of modern world landscape (Utusan Online, 2017). These revolutions mark the existence of physical cyber system which includes the new overall ability of humans, machines and new technological methods. In other words, the automation technology is seen as having a technological ability which does not require direct involvement of humans.

Realising the advancement of this technology, the information technology and communication (ICT) in today's $21^{\text {st }}$ century has also given attention to a few matters to ensure that the technology used in education fulfills the needs of HOTs among students and students. There are seven main components in ICT literacy, which are (i) defining, (ii) accessing, (iii) managing, (iv) integrating, (v) evaluating, (vi) creating, and (vii) communicating (Abdul Manaf et al., 2015). Hence, teachers should ensure that they have the capability to carry out effective T\&L by using the transition of mobile technology in education as a challenge and not a hindrance or even a problem for them (Mohd Salmi Osman et al., 2015).

\subsection{Cultivating HOTs in T\&L in Malaysia}

Education curriculum in Malaysia is imbalanced and focuses on factual-based input that is abstract and difficult to be mastered by students due to the ignorance of the development of their right brain (language, literature, aesthetics, sports, creativity and art talents) and excessive attention is given to the development potential of the left brain (academic matters, which consist of analytical and logical mathematics). Pedagogical process that is done by teachers may sometimes be prone to be teacher-centred. On the contrary, teachers should practise pedagogical practice that is thematic (student-centred) and is strengthened by the revampment of the new curriculum so that learning will be more significant to students by instilling the education elements that encourage them to think and apply the information in their daily life (Aminah Ayob, 2003).

In planning the mould of Malay Language education system, the integration of teaching skills in T\&L is crucial as stressed by Maimunah Osman (2004) who explained that thinking practice should be nurtured in each individual continuously and should be given early emphasis at schools 
and higher learning institutions. Supportive conducive environment to open doors for vast exploration opportunities, trials, trainings and improvement are required to realise the effort to instill the culture and ability of the individuals to think continuously. The production of quality output can be done through techniques that encourage thinking skills besides the existence of environments that aid students to think well. In fact, strengthening students' cognitive is also done through planning and conducting thinking activities in groups. Students have to be exposed to the culture of divergent thinking by looking at some matters from various perspectives and not only restricted as receivers of knowledge, as they are also taught to be those who seek for diverse knowledge. Thus, teachers have to prepare various plans, practice and alternatives to be discussed so students could sense the ultimate meanings that form the base of certain questions.

In the hope of cultivating thinking skills as the main element to progress T\&L, Malay Language teachers should be aware of some questions that have turned into a dilemma in using HOTs. Among the questions is, "How does one produce or integrate a process of thinking or an experience of thinking in a language instruction?" (Kamsiah Abdullah, 2002). This issue will definitely be a nightmare to teachers since the cultivation of thinking skills strategy in the process of T\&L needs to be systematically planned instead of being spontaneously done. Subsequently, the change in education pedagogical field focuses on how thinking process is carried out besides ensuring the product quality of the learning outcome from the thinking activity. Besides that, there are also other questions on (1) how thinking ability could give new added value which could elevate T\&L to a better level; (ii) what makes a learner different from other students, (iii) how to create something that did not exist in the past; (iv) how to develop a new thinking pattern; or (v) how to improve something in a new alternate way. All these questions have to be scrutinized and overcome fairly in the effort to cultivate HOTs in Malay Language education (Maimunah Osman, 2004). If Malay Language teachers are clear about the objectives of using thinking skills, they will be able to interpret their insightful holistic ideas into the form of effective T\&L.

Looking at the importance of cultivating continuous HOTs in T\&L, various sectors should contribute their expertise towards the planning of new curriculum. Curriculum change is divided into two categories, which include the current restructuring and the replacement of existing curriculum in education system. The implementation of HOTs falls in the second category, whereby HOTs act as a continuation to the existing KBKK, which has been a practice in the previous T\&L process (Abdul Halim Abdullah, 2016). The paradigm shift of Malaysian education system is seen to take place through the implementation of KSSR beginning in 2011, followed by the introduction of Kurikulum Standard Sekolah Menengah (KSSM) in 2017 in all schools nationwide. The introduction of the new curriculum system is a sign of respect to PPPM 2013-2025 besides the RM500 million additional grants given to realise PPPM 2013-2025. Moreover, KPM has given attention to a lot of changes in teachers' teaching approaches in classrooms through the preparation of source management efforts to provide trainings and programmes that are accepted by teachers to boost their knowledge of HOTs. The change in teachers' pedagogical approach also includes the application of $\mathrm{KBKK}$, the introduction of mind mapping i-Think programme, questioning technique, mind mapping, compare-contrast, and the six thinking hats as thinking tools that assist teachers to form the values of HOTs, to create original ideas that are generative in learning, besides being able to evaluate the relevance of each idea using evaluative attitude (Abdul Halim Abdullah, 2016).

The final change involves the aspect of assessment in the process of T\&L. In $2016,40 \%$ of HOTs questions were integrated in UPSR, while $50 \%$ of the questions were integrated in SPM to improve the central assessment system carried out by LPM in comparison to 2013, whereby only a small percentage of $10 \%$ was involved for both central examinations. For the next implementation of HOTs, the product of HOTs from specific programmes will be assessed through the national and international assessments such as Trend in Mathematics and Science Study (TIMSS) and Programme International Student Assessment (PISA). To sum up, the cultivation of thinking skills in life acts as a major development of civilization in the evolution of society. The practice of intellectual thinking tradition could propel the prestige of language and advanced race to create more progressive thinkers that are dynamic and powerful, as proven in history that clearly showed the glory of relevant and timeless thinking culture (Nur Hidayah Ismail, 2015). It is essential that decent and active thinking culture is able to determine how far a society could grow to reach success. This is shown in Figure 1.0 on the HOTs implementation framework in the education system in Malaysia in a holistic manner. 

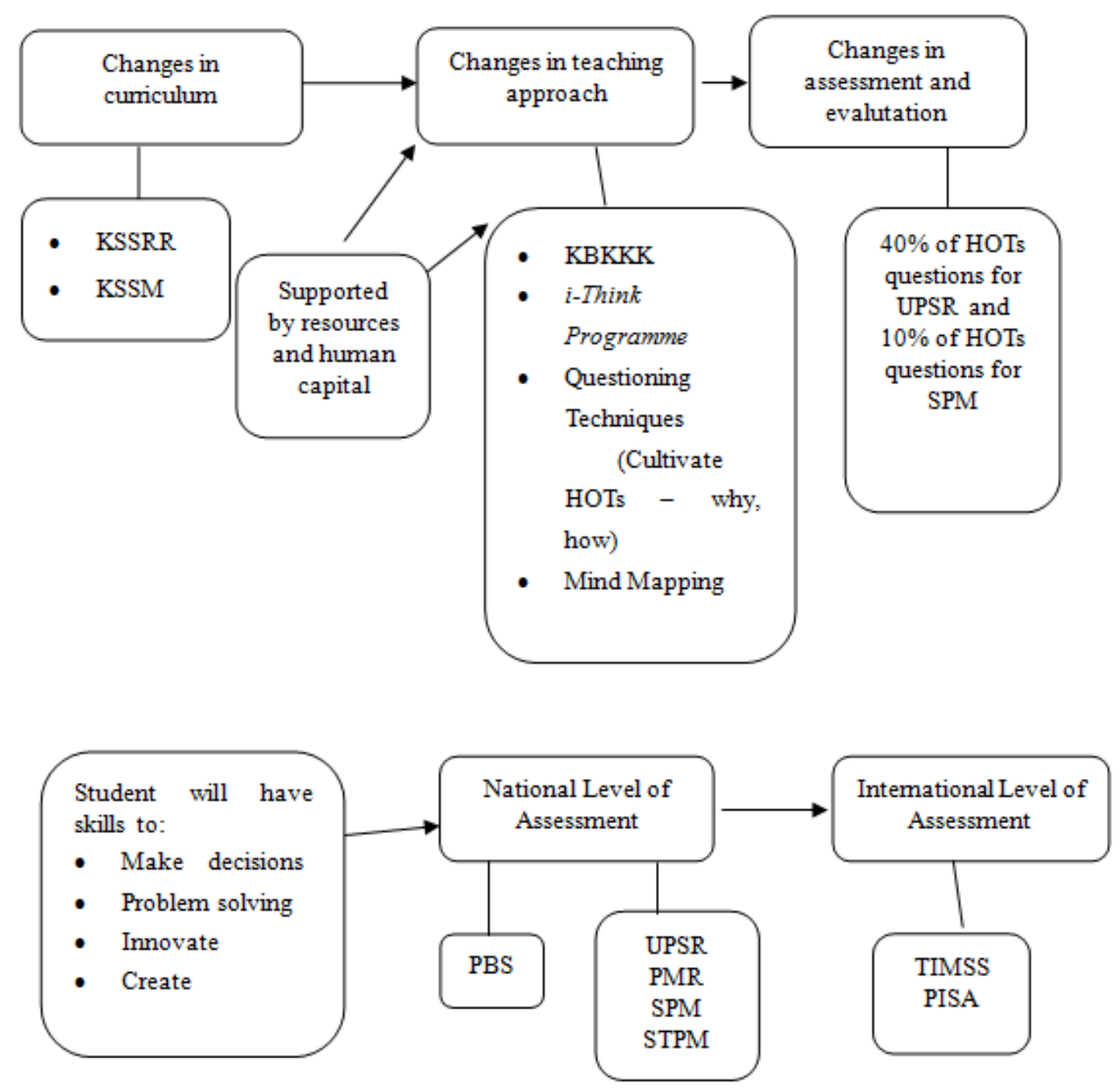

Figure 1. The Framework of the Implementation of HOTs in Malaysian Education system

In the $21^{\text {st }}$ century, the work burden of teachers is getting more challenging. Other than teaching task, teachers are also burdened with clerical work, being the facilitators, motivators, planners, co-curricular advisors and club leaders, sports coaches ; and are also involved in associations, uniform bodies and many more. Other than academic task, teachers are tasked with various positions such as chairman of the committee, committee members as well as other side work which lessen their focus on their main task, which is teaching (Siti Hajar Halili \& Suguneswary, 2016). Therefore, teachers are unable to spend more time to prepare teaching aids that are based on mobile technology in the teaching process.

It is vital for teachers to have a positive perception on the use of mobile technology in the T\&L of Malay Language. Positive teachers' acceptance of the use of mobile technology shows the ability of an educator or a teacher to accept a tool or a person for the purpose of improving the process of T\&L to follow the shift of focus on mobile technology in teaching. In this context, the acceptance of teachers refers to their level of willingness to use mobile technology based on the teachers' mastery of information technology and communication in the T\&L of Malay Language. There are three main aspects that facilitate the teachers' readiness to use mobile technology in $T \& L$, which are (i) the perception on the facilities of mobile technology; (ii) the skills of using mobile technology; and (iii) the attitude of teachers towards the acceptance of mobile technology usage (Siti Hajar Halili \& Suguneswary, 2016).

Besides that, research findings also showed that the perceptions and attitudes of teachers could change if they are given trainings or courses on the preparation of teaching materials based on mobile technology. This is because teachers are being optimistic about the use of mobile technology as an aid in T\&L; realising that mobile technology is important in today's life; having the negative change to positive perceptions, and experiencing the increase of confidence through the use of mobile teaching in T\&L. Therefore, attitude and awareness are the best ways to expect and predict the commitment towards the use of mobile technology in T\&L. Attitude and confidence as 
well as high efficacy among teachers will assist the smooth process of increasing the acceptance of mobile technology in $\mathrm{T} \& \mathrm{~L}$ in classrooms.

\section{2. $T \& L$ in the $21^{\text {st }}$ century: The Use of Mobile Device}

$\mathrm{T} \& \mathrm{~L}$ process requires effective teaching strategy to reach the learning objective. This is because the use of mobile technology gives consideration to a few aspects, which are (i) it functions as a multimedia approach that is linked to the presentation; (ii) it uses interaction through the simulation available in the market or industry for education; (iii) the interaction through simulation, which is developed, has to balance between education and fun in learning (Nurul Syazwani Ismail, Jamalludin Harun \& Shaharuddin Md. Salleh, 2016). Besides that, the use of mobile technology that is based on the pedagogical approach also considers a few important aspects that include the appropriateness of real time, the needs of students and the assessment and grading.

In the education world, the revolution of mobile technology should be seen as a new pedagogy in delivering the content of knowledge to students. In realisation of this fact, teachers and the practitioners of Malay Language should not be left behind in finding opportunities to make mobile technology as a scaffold that eases T\&L instructions in classrooms. Consecutively, mobile technology usage could also function as a communication tool that drives the sharing of knowledge in T\&L. This scenario clearly confirms with the view that the use of mobile devices is not merely a matter of desire, but it is a requirement in T\&L. Furthermore, the dependency on mobile technology has given impacts on the change of learning pattern and style of students because of its total usage since it is easily accessible, affordable and precise. Students do not need to commute from one place to the other to gain knowledge or information because of the mentioned situation.

Therefore, it is clear that the trend towards the shift of mobile technology exists in Malaysia as more people are using it in T\&L, may it be at school level or higher education level. The shift of the focus on mobile technology is predicted to have the capacity to offer space for teachers and students to have two-way interaction in T\&L. Teachers have to be prepared to face informal learning situations since students will take the opportunity to use mobile devices to contact teachers, to find information for the needs of T\&L, to browse the Internet to find relevant topics, to download sources, to find meanings of terms or to find questions for exercises (Nurahimah Mohd Yusoff \& Muhammad Nidzam Yaakob,2016). Based on the level of awareness, it is important for teachers to develop teaching materials that implement HOTs in future T\&L.

\section{Conclusions}

Teachers are the main catalyst for the implementation of effective and exciting language teaching because teachers are seen as the "primary source in language and language learning" (Muhammad Zuhair Zainal, 2017). Notably, teachers are responsible to create the elaboration of content by using creative speech and communication skills to engage students' participation during T\&L process of Malay Language. Hence, the use of mobile technology will lighten the burden of teachers and help them implement effective pedagogy besides cultivating HOTs among students.

\section{Acknowledgements}

We are very grateful to experts for their appropriate and constructive suggestions to improve this template.

\section{REFERENCES}

[1] A.Rahman Haron, Jamaludin Badusah \& Zamri Mahamod. (2015). Kemahiran Berfikir Aras Tinggi (KBAT) dalam Salak Didik dengan Elemen Nyanyian dan Elemen Pantun. Jurnal Pendidikan Bahasa Melayu, Vol. 5 Bil. 1 Mei, pg. 53-60.

[2] Abdul Halim Abdullah. (2016). Kemahiran Berfikir Aras Tinggi (KBAT) Dari Aspek Kurikulum, Pedagogi dan Pentaksiran. In Johari Surif, Nor Hasniza Ibrahim, Abdul Halim Abdullah \& Yusof Boon, Kemahiran Berfikir Aras Tinggi dalam Pengajaran dan Pembelajaran (pg 127-149). Skudai: Fakulti Pendidikan Universiti Teknologi Malaysia.

[3] Abdul Manaf, S.Z., Din, R., Hamdan, A., Mat Salleh, N.S., Kamsin I.F., Karim, A. A. Mohd Fauzi, I. F., Zaid, A.S., \& Ismail, N.M., (2015). Pembelajaran Peribadi melalui Teknologi ICT Abad ke-21 ke arah Kemahiran Boleh Pindah. Journal of Personalized Learning, 1(1), pg. 57-68.

[4] Aliff Nawi, Mohd Isa Hamzah \& Surina Akmal Abd Sattai. (2017). Potensi Penggunaan Aplikasi Mudah Alih (Mobile Apps) dalam Bidang Pendidikan Islam. The Online Journal Of Islamic Education July 2014, Vol. 2 Issue 2

[5] Alizah Lambri \& Zamri Mahamod (2015). Pelaksanaan Aktiviti Pembelajaran Berasaskan Masalah dalam Proses Pengajaran dan Pembelajaran Bahasa Melayu. PENDETA - Jurnal Bahasa, Pendidikan \& Sastera Melayu Vol. 6, pg. 98-116.

[6] Aminah Ayob. (2003). Siri Syarahan Umum Pelantikan Profesor Pelantikan 2003/Bil.2.Permbelajaran Berasaskan Minda dan Implikasinya kepada Pendidikan. Penerbit Universiti Sains Malaysia. Aznan Omar. (2017). Permainan Mudah Alih dan Kanak-kanak. Idealogy, 2(1), pg. 137-149. 
[7] Badrul Hisham Alang Osman \& Mohd Nasruddin Basar. (2016). Amalan Pengajaran dan Pembelajaran Abad Ke- 21 dalam Kalangan Pensyarah Institut Pendidikan Guru Kampus Ipoh. Jurnal Penyelidikan Dedikasi Jilid 10, pg. $1-25$.

[8] Baharuddin Jabar. (2006). Perspektif Pelajar terhadap Pengajaran Kemahiran Berfikir ArasTinggi dalam Pengajaran dan Pembelajaran Sejarah di Seko lah Menengah: Satu Kajian Kes Di Daerah Hilir Perak. Laporan Geran Penyelidikan. Fakulti Sains Sosial dan Kemanusiaan: Universiti Pendidikan Sultan Idris.

[9] Chew Fong Peng \& Shashipriya Nadaraja. (2014). Pelaksanaan Kemahiran Berfikir Kreatif dan Kritis dalam Pengajaran dan Pembelajaran Komsas di Sekolah Menengah. Jurnal Pendidikan Bahasa Melayu Vol. 4, Bil. 2 Nov, pg. 10-24.

[10] Fuziah Rosman, Norlidah Alias, Mohd Nazri Ab Rahman \& Dorothy Dewitt. (2016). Reka Bentuk Kurikulum Permainan Video Bahasa Melayu di Institusi Pengajian Tinggi Awam (IPTA).

[11] James Ang Jit Eng. (2017). Pembelajaran dan Pemudahcaraan (PdPc) In Pasukan Pemikir Abad Ke-21, Panduan Pelaksanaan Pendidikan Abad Ke-21. Bandar Enstek, Nilai Institut Aminuddin Baki.

[12] Kamsiah Abdullah. (2002). Bahasa dan Pemikiran Rangkaian Penelitian. Singapura: Majlis Bahasa Melayu Singapura.

[13] Khairah@ Asma'a Baharun, Saedah Siraj \& Muhammad Faizal A. Ghani. (2017). Aplikasi Pesanan Segera Mudah Alih (Mobile Instant Messaging) dalam Pembelajaran Kolaboratif: Satu Kajian Analisis Keperluan. Jurnal Kepimpinan Pendidikan, Januari, Bil. 4, Isu 1, pg. 35-49.

[14] Md.Yusof Dawam. (2006). Mengajar Kemahiran Berfikir Dalam Mata Pelajaran Bahasa Melayu di Sekolah Rendah: Satu Kajian di Sebuah Sekolah di Mersing, Johor. Disertasi Ijazah Sarjana. Fakulti Bahasa: Universiti Pendidikan Sultan Idris.

[15] Maimunah Osman. (2004). Kemahiran Berfikir Siri Pengurusan INTAN. Kuala Lumpur: Institut Tadbiran Awam Negara (INTAN).

[16] Maszuraini Miswan \& Hamedi Mohd Adnan. (2015). Pembangunan Aplikasi Peranti Mudah Alih untuk Kemahiran Membaca Kanak-Kanak: Aplikasi Literasi LINUS (LiLIN). Aplikasi Literasi LINUS (LiLIN), Jld. 17, Bil. 2, pg. 64-78.

[17] Mohd Nazri Hassana, Ramlee Mustapha, Nik Azimah Nik Yusuffa, Rosnidar Mansor. (2017). Pembangunan Modul Kemahiran Berfikir Aras Tinggi di dalam Mata Pelajaran Sains Sekolah Rendah: Analisis Keperluan Guru. Sains Humanika 9: 1-5, pg. 119-125.

[18] Muhamad Sidek Said. (2016). Memupuk Budaya Berfikir Aras Tinggi Melalui Kemahiran Mengkategori dalam Kalangan Kanak-Kanak Pra Sekolah. Prosiding Seminar Penyelidikan Tindakan Pendidik Guru 2016 "1 Pensyarah 1 Penyelidikan”. (Pg. 431-439). Besut : Institut Pendidikan Guru Kampus Sultan Mizan.

[19] Muhammad Zuhair Zainal. (2017). Lakuan Ilokusi Guru dalam Pengajaran Bahasa Melayu. GEMA Online® Journal of Language Studies Volume 17(4), November, pg.
191-208.

[20] Musliha Salma Mohd Radzi. (2010). Aplikasi Kemahiran Berfikir Aras Tinggi Melalui Pembelajaran Berasaskan Masalah. Disertasi Ijazah Sarjana Muda Teknologi serta Pendidikan (Kejuruteraan Awam): Fakulti Pendidikan Universiti Teknologi Malaysia.

[21] Nooriza Kassim \& Effandi Zakaria. (2015). Integrasi Kemahiran Berfikir Aras Tinggi dalam Pengajaran dan Pembelajaran Matematik: Analisis Keperluan Guru. Jurnal Pendidikan Matematik, 3 (1), pg. 1-12.

[22] Noor Aini Ahmad. (2014). Mengintergrasi Teknologi Komunikasi dan Maklumat sebagai Media PengajaranBahasa dalam Kalangan Kanak-Kanak Awal Umur. Jurnal Pendidikan Bahasa Melayu, Vol. 4, Bil. 2 (Nov), pg. 36-43.

[23] Nurahimah Mohd Yusoff \& Muhammad Nidzam Yaakob. (2016). Analisis Fuzzy Delphi terhadap Halangan dalam Pelaksanaan Mobile Learning di Institut Pendidikan Guru. Jurnal Penyelidikan Dedikasi Jilid 11, pg. 32-50.

[24] Nur Hidayah Ismail. (2015). KBAT Pendidikan Abad Ke-21. Pelita Bahasa, Bil 3, pg. 10-13.

[25] Nurul Syazwani Ismail, Jamalludin Harun \&Shaharuddin Md. Salleh (2016). Teknologi Mudah Alih dalam Meningkatkan Kemahiran Berfikir Aras Tinggi Pelajar. Pg 202-210.

[26] Owi Wei Ping \& Ang Kean Hua. (2017). Education in Malaysia: A Review. International Journal ofResearch, Volume 04 Issue 02 February, pg. 319-327.

[27] Siti Hajar Halili \& Suguneswary. (2016). Penerimaan Guru terhadap Penggunaan Teknologi Maklumat dan Komunikasi Berasaskan Model TAM dalam Pengajaran Mata Pelajaran Bahasa Tamil. Jurnal Kurikulum \& Pengajaran Asia Pasifik, April, Bil. 4, Isu 2, pg. 31-41.

[28] Supramani, S. (2006). Penyoalan Guru: Pemangkin Pemikiran Aras Tinggi Murid. Jurnal Pendidikan Universiti Malaya, pg. 225-246.

[29] S. Z. Abdul Manaf, R. Din, A. Hamdan, N. S. Mat Salleh, I. F. Kamsin \& J. Abdul Aziz.(2015). Penggunaan Komputer dan Internet Web 2.0 dalam Kalangan Generasi Y Pelajar Universiti. Journal of Advanced Research Design, Vol. 7, No.1, pg.10-18

[30] Shamsuddin Muhammad, Ruzlan Md. Ali \& Siti NoorIsmail. (2016). Tahap Amalan Penerapan KemahiraPemikiran Kritis (KPK) di Sekolah Menengah Berprestasi Tinggi, Sederhana dan Rendah.International Seminar On Generating Knowledge Through Research. (Pg. 967-976). Sintok: UUM-UMSIDA. 25-27 Oktober 2016.

[31] Sharifah Nor Puteh, Nor Adibah Ghazali, Mohd Mahzan Tamyis \& Aliza Ali. (2012). Keprihatinan Guru Bahasa Melayu dalam Melaksanakan Kemahiran Berfikir Secara Kritis dan Kreatif. Jurnal Pendidikan Bahasa Melayu November Vol., Bil 2, pg. 19-31.

[32] Siti Ezaleila Mustafa \& Azizah Hamzah. (2011). Media Baharu Yang Baharu: Trend Penggunaan Jaringan Sosial dalam Kalangan Pengguna di Malaysia. Jurnal Pengajian Media Malaysia, Vol. 13, No. 2, pg, 93-110.

[33] Suhaimi Zakaria@ Othman, Baharuddin Aris, Hasnah 
Mohammed, Norasykin Mohd Zaid \& ZalehaAbdullah. (2014). Penerapan Kemahiran Berfikir Aras Tinggi Melalui Model Stesen Rotasi Pelbagai Mod. Konvensyen Antarabangsa Jiwa Pendidik 2014. (Pg. 1-16). Johor Bahru: Fakulti Pendidikan, Universiti Teknologi Malaysia. 11-13 Ogos.

[34] Sukiman Saad, Noor Shah Saad \& Mohd Uzi Dollah. (2012). Pengajaran Kemahiran Berfikir: Persepsi dan Amalan Guru Matematik Semasa Pengajaran dan Pembelajaran di Bilik Darjah. Jurnal Pendidikan Sains \&Matematik Malaysia, Vol.2 No.1, pg. 18-36.

[35] Tee Tze Kiong, Jailani Md Yunos, Widad Othman, Baharom Mohamad, Yee Mei Heong \& Mimi Mohaffyza Mohamad. (2011). Pembangunan dan Penilaian Kualiti Modul Pembelajaran Kendiri Kemahiran Berfikir dan Peta Minda Buzan. Seminar Pasca Ijazah dalam Pendidikan 2011 (Pg. 67-92). Skudai: Fakulti Pendidikan Universiti Teknologi Malaysia.

[36] Yahya Othman. (2009). Keutamaan Bahan dalam Pengajaran dan Pembelajaran Bahasa Melayu pada Sekolah-Sekolah di Selangor Darul Ehsan, Malaysia. SOSIOHUMANIKA, 2(2), pg. 216-226.

[37] Yahya Othman. (2014). Peranan Guru Bahasa Melayu dalam Merangsang Kemahiran Berfikir Aras Tinggi. Dewan Bahasa. Bil 14 (5), pg. 20-24.

[38] Wan Mat Sulaiman \& Norkhairiah Hashim. (2011). Aplikasi Kemahiran Berfikir dalam Pengajaran Pengetahuan Ugama Islam. Journal of Applied Research in Education, Vol 15, No.1 \& 2, pg. 43-58.

[39] Zarina Abdul Rashid. (2016). Tahap Kesediaan Guru Dalam Aspek Pengetahuan dan Keperluan Latihan Berfokuskan Aplikasi KBAT. Disertasi Ijazah Sarjana Pendidikan Teknikal (Rekabentuk Instruksional \& Teknologi). Fakulti Pendidikan Teknikal \& Vokasional : Universiti Tun Hussein Onn Malaysia.

[40] Zulkifli Osman. (2015). Kemampuan Model Pengajaran Bahasa Melayu Berdasarkan Kemahiran Berfikir melalui Teknologi Maklumat dan Komunikasi Meningkatkan Tahap Motivasi dan Kemahiran Bahasa Pelajar. PENDETA - Jurnal Bahasa, Pendidikan \& Sastera Melayu, Vol. 6, pg. 181-213. 